\title{
Germany stunned by institute closures
}

Munich. Germany's Max Planck Society (MPS) shocked the country's scientists by announcing last week that it plans to close four of its institutes in the western part of the country to meet government demands for staff cuts. Further closures are likely.

Hubert Markl, president of MPS, says the closures are needed because the federal government, which provides half the research organization's funding, unexpectedly ordered a 5 per cent cut in staff, equivalent to 320 posts, earlier this month. This comes on top of the 420 staff that the MPS had already been told to shed by 1998 .

Following Germany's reunification, the society has had to streamline western institutes to allow new ones to be established in the east, and it has already made cuts to achieve this. As a result, the new staff savings cannot be spread across all the institutes without affecting efficiency, according to Edmund Marsch, MPS deputy general secretary. He warns that the closure of the four institutes will only result in half of the required staff savings, and further closures will therefore follow.

Three of the institutes earmarked for closure are the Institute for Aeronomy in Lindau, Niedersachsen, with 185 staff, the Institute for Biology in Tübingen, Baden-
Württemberg, with 93 staff, and the small Institute for Human Ethology in Andechs, Bavaria. The fourth has not yet been named because its director is currently abroad.

Marsch stresses that the closure decisions were not based on the scientific performance of the institutes. A significant factor in deciding which institutes to target, he says, was the impending retirement of their respective directors. The MPS often chooses to close a department after the retirement of its director. But this is the first large-scale closure of whole institutes.

Closure of the Institute for Human Ethology will be almost immediate. But the last of the four directors of the Lindau institute will retire in ten years' time, and in Tübingen the last director is due to retire in 2004, so these institutes will be wound down slowly. That will be hard on scientists who will feel they are working under a death sentence, says Peter Overath, scientific director at the Institute for Biology.

The institutes were unaware that closures were imminent. Only two weeks before the announcement, says Overath, the Institute for Biology had hosted a symposium at which candidates to replace two of the retiring directors delivered lectures as part of the normal selection procedure.
A spokesman for the Institute for Aeronomy says the institute had hopes of being a major player in Rosetta, the cornerstone mission of the European Space Agency (ESA) which will fly into a comet nucleus, and this could now be thrown into doubt.

According to David Southwood, former chairman of ESA's Science Programme Committee, the loss of the institute's expertise in high-quality instrumentation would be serious not only for Germany but for the many other countries that collaborate with it on space science. But Marsch says that the work at the institute is no longer a priority for the society.

Markl's closure plans will be discussed on Friday 18 October by the MPS's technical committees. The society's senate will vote on the overall plan on 22 November, and the individual closures will be put to a vote of a senate meeting next spring. Meanwhile targeted institutes are preparing their defence, in the hope that the society may be persuaded to change its mind. But Markl has said from the beginning of his term as president that he will not shy away from difficult decisions about institute closures in west Germany (see Nature 381, 357; 1996).

Alison Abbott \& Quirin Schiermeier

\section{Clinton hooks on to science as 'a bridge to the future'}

Washington. Science has emerged as a prominent theme of President Bill Clinton's campaign speeches as he travels around the country promising to build "a bridge to the 21st century" if - as widely expected - he is re-elected to a second four-year term on 5 November.

Last week, for example, Clinton praised the Human Genome Project, cancer and AIDS research, space science and the Internet, in remarks at campaign stops around the country. He and Vice-President Al Gore accused Bob Dole, the Republican candidate, of planning across-the-board cuts in research funding and argued that Dole's plan to abolish the Department of Energy would endanger several national laboratories.

Speaking in Knoxville, Tennessee, Clinton pointed out that all five US winners of this year's Nobel prizes in physics and chemistry had been funded by the federal government through the National Science Foundation (NSF). "Cutting back on research at the dawn of a new century would be like cutting our defence budget at the height of the Cold War," he said. "We must not do it and we will not do it."

Clinton singled out the Human Genome Project as "one of my favourites", promising his audience that "it won't be too many years before parents will be able to go home from the hospital with their new-born babies with a genetic map in their hands that will tell them: 'here's what your child's future will likely be like'.

Clinton has rarely mentioned science during his first four-year term, and political commentators suggest that his apparent interest now is merely part of a strategy to make 73-year-old Dole look old-fashioned. The Dole campaign has not responded directly to the attacks.

Gore, worried that the loss of his home state of Tennessee could disrupt his rise as the likely Democrat presidential nominee in 2000, told the Knoxville audience that Dole had "proposed measures that would clearly shut down" the nearby Oak Ridge National Laboratory. "President Clinton and I will not let that happen," he pledged.

But the prospects for serious discussion of the science issues that divide the two camps - such as the future of the Department of Energy - receded with the cancellation of plans by the American Association for the Advancement of Science (AAAS) for a debate on them in Washington.

Mary Good, assistant secretary at the Department of Commerce, and Robert Walker, the retiring chairman of the science committee in the House of Representatives, had been lined up to represent the Clinton and Dole campaigns respectively in the forum on 22 October. But the AAAS cancelled it late last week.

With Clinton's 15-point lead in opinion polls holding steady since early summer, attention is beginning to drift from the campaign to the nature of a second Clinton administration. Jack Gibbons, the president's science adviser, is expected to retire, and his choice of Good to represent Clinton in the aborted debate reinforced her status as front runner to succeed him.

A former chemistry professor and industrial research manager, Good's energy and directness would, in the eyes of science lobbyists, more than compensate for her lack of top-rate scientific credentials. Other names in the ring are Ernest Moniz, a physicist currently assisting Gibbons, James Baker, the administrator of the National Oceanic and Atmospheric Agency and - curiously - Dan Goldin, the administrator of NASA.

Neal Lane has a six-year term as director of the National Science Foundation, ending in 1998, which he would like to complete, and Harold Varmus, director of the National Institutes of Health, is also expected to stay on. Hazel O'Leary, the energy secretary, will almost certainly leave and, despite efforts on Capitol Hill to rally support for Charles Curtis, her well-respected deputy, to succeed her, a political appointment from outside the department is likely. Colin Macilwain 